\title{
Integrative Values of Folktales: Igbo Folktale Example
}

\author{
Nnadi, Catherine Chiaka \\ Department of Igbo, Adeyemi College of Education, Ondo
}

\begin{abstract}
The indigenous language of a people is the most accepted medium of communication. It enshrines and translates the peoples' life (culture) as domesticated in their norms, values and morals. Adopting the functional perspective to sociological studies, this paper aims at x-raying the values of folktales (Igbo Folktale), for the formation of well behaved, self- reliable, accommodating, responsible and responsive individuals for progress and harmonious communal existence. These virtues which form the bases for training in the society are encapsulated in the people's folktales shared commonly at family and communal leisure times. Folktale as a genre of oral literature is built into written literature courses in schools. However, modernity, development and quest for greener pasture deny people of the opportunity to enjoy the leisure for cultural learning / training avenues. Schools are no longer performing the expected role. Hence, these cultural virtues are left hanging in the balance. This study therefore tends to illustrate the rich availability of the virtues necessary for national integration with the analysis of three Igbo folktales. Deductions from these folktales confirm the richness of societal values. It concludes by underlining the need for the reintroduction of indigenous language study and folktale in schools.
\end{abstract}

Keywords:- Integration, Folktale, Language, Igbo Language.

\section{INTRODUCTION}

Integration simply means fusing/merging /uniting of different parts, elements, entities, ethnic groups together. National integration can be described as the efforts within the civil society at knitting together disunited heterogeneous groups for peaceful existence aimed at realization of a common national goal. This definition collaborates Dudley (1973) in Adu-Peters (2011:22) definition of nation building "... knitting together of threads that holds a political entity together for a sense of purpose". However, Adu-Peters (ibid), clarify on the laps that follow the inappropriate implementation of the visions for the amalgamation (integration).

This artificial origin coupled with alien principles of government through the orchestration of non-compliant constitutional arrangement that utmost pursued the biased interest of the colonial powers, the immediate desire for self-government by the early elites who carelessly neglected the agitation for economic and social independence for political independence of "now", ushered the entire polity into an incompatible dispensation of sociopolitical and economic entanglement."

The implication of the above assertion is that, there was a common ambition and objective for the quest for freedom which was jeopardized for an un0envisaged and planned pursuit, for the fact that an unplanned purpose was achieved; the aftermath did not satisfy the needs of the people. The reason for that was that:

The creation of Nigeria's a single political entity called for the coming together of people of various nationalist under a single territorial and institutional framework. The various nations that made up "Nigeria" were not effectively integrated towards evolving a time sense of national identity and commitment to the nation. The political consciousness that might have enhanced a sense of inter-group relations within Nigeria took a form of ethnic chauvinism which emerged with the politicization of the different cultural and ethnic elements. Ibid (23).

Though ethnic political chauvinism was a clog in the wheel for nationhood (integration), it did not out rightly deter the vision of national integration since independence in 1960 . The unity schools, federal character principles, the National Youth Service Corps (NYSC) scheme, the indigenous language teaching and learning as stipulated in the National policy on education (9181) and state creation are all policies intended towards the achievement of national integration. The effective and purposeful implementation of all these are dependent on the citizens; the unity schools, National Service Corps (NYSC), Federal character principle and the indigenous languages teaching and learning are majorly youth oriented programs. The fruitfulness of these programs are dependent on the levels of the recipients (Youth) acceptance and effective participation because individuals are the units of integration, and members a nation are integrated as they share a common identity One of the process of implementation involves the harboring of the youths from the different ethnic groups together. Coming from various cultural backgrounds with varied views on the same items is as good as bringing the dead, blind dumb together, with each fighting to maintain his/her identity and belief.

To salvage the situation, the indigenous language policy was introduced, where Nigerian child was required to study one major language (Hausa, Igbo or Yoruba) in addition to His/her mother tongue. Language is part of the peoples' culture as well as the medium of teaching. 'Language and culture are intricately related and dependent on each other. Language is formed by culture while culture 
is influenced and impacted by language. Language is the medium of culture (the entire way of life of a people)' Darionne (2016). The culture of the people is as depicted in their values, morals, attitudes, beliefs, customs e.t.c which makes them who they are, controls their relationship and forms their world view. These elements of the society are inculcated in the individuals under the traditional education via oral literature and traditions such as folktales (akuoifo), proverbs (ilu), panegyric (mbem), chants (mkpoku). 'These are expressions or formulations of people's feelings or ideas about real human experience, preach morals and emphasis communal values for integrating groups and giving them a sense of belonging' (Raji 2009:302; \& Ojo, 2018:139).

However, with the rapid rate of urbanization, large scale migration, industrialization, environmental change and influence of internet age, our children's curiosity to hear stories of the past, stories of wisdom form the elderly meant for social integration is now replaced with rapt attention to devices - laptops, iPad and smartphone. This has to a large extent alienated the youth from learning the societal norms, wisdom, value, ethics, philosophy, customs and likes which are residual in the folktale and other genres of oral literature Consequent upon this is the high increase in social vices such as kidnappings, money rituals, incessant killings, rise of militant groups, destruction of oil pipeline to mention but a few, in our nation today. This study therefore demonstrates the extent which society's cultural knowledge in the folktale (Igbo folktale) is of great value in integrating Nigerians for the desired development.

\section{THEORETICAL FRAMEWORK}

This study adopts the functional perspective to sociological studies in considering how and why folktale is so valued that it is considered inevitable in the formation of the individuals within the society for social order. Emile Durkheim (1868-01917) in Fataroti (2016:348); acknowledged proponent of sociological theory, was particularly interested in understanding how social order is possible or how society can remain relatively stable in order to enable citizen live happily within gamut of the society's simulative etiquettes. Functionalism focuses on the consensus and order that exist in the society with keen interest on social stability and established public values. Balogun (1983:55) in Ikeokwu (200) sees the functional approach of studying folktales as ' comprehending man not only as an individual who must be encouraged through moralistic tales to great personal achievements, but also an integral member of a society". The implication of this is that deviation from the society values as expected from the individuals or group of people in the society results in draw back on the social stability. Therefore, lessons in the folktales are inbuilt strategy aimed at checking the individual's excesses. One reason for this is that the individuals within the society are independent; what one does has a retributive consequence on the cohesion of the society

\section{CONCEPT OF FOLKTALE}

Folktale belongs to the class of oral literature. In the opinions of Acholonu (1985:49-101) Olajubu (1987) kofowora (1981) in Arohunmolase (2000:360) 'Hausa, Igbo and Yoruba group all have this form or oral literature as a custodian of their oral tradition. Be that as it may, it was educative for the young ones and a source of intellectual exercise for adults_and those who were well established. Acholonu (1985) in Arohunmolese(2000:359). As oral tradition, it is passed orally from generation to generation. Therefore, they are stories that grew out of the lives and imaginations of the people or folk. They often contain a lesson to be learned, and can take many forms, like fables, tell tales and even ghost stories, fairy tales, trickster tales, myth and legends -Aarons world of stories- folktale (www.aaronshop.com $>$ stories $>$ folk)

Among the Igbo of Nigeria, folktales constitute the moral and ethical component of the people's culture and philosophy. They constitute the traditional beliefs and customs passed orally, either during moon light or around the fire at night. Folktales are very germane in the inculcation of appropriate knowledge to the younger generation. The central knowledge which is the culture- the constitution of the behavior of the people and contains what the people consider moral excel of existence. Akubuiro (2018) asserts that folktale (sic) are used to pass knowledge, cultural and social values as well as collective memory and played a crucial part in keeping culture's alive. Young ones were taught manners, customs and were imbued with the attitude and values basic to their culture. It also constitutes of behavior/attributes which society considers deviant and inappropriate. Ibeh (2016:11) explains that Igbo folktale is powerful tools that carry norms, values, behaviors and patterns of life. It is one of the genres of traditional fiction prose narrative deployed to pass moral instructions-Khalid Iman (Ibeh, 2016:11)

Folktale is mostly associated with younger ones. This according to Piaget (Ibid) ' Knowledge is constructed when individuals engage socially in talk and activity about shared problems or task'. Folktale is an activity that allows children to interact and to retain memory what he/she learnt from the story told- Ibeh (2016:Ibid). They appeal to the child's sense judgment and goes a long way in forming or shaping the life of the child. Whatever that is appropriately learnt from childhood can hardly be forgotten. From folktales, the younger ones learn that good behaviors are rewarded while deviant ones are punished. "it is clear that education makes man moral and ethical; inducts the individual into shared values of society develops commitment to societal goals in the individual, prepare the young members of the society for the future; defines behavioral patterns of individuals and society and also enhances the productive capabilities of individuals and by extension the society" - eaglesislandtech.blogspot.com 
This summarizes the fact that folktale is a form and process of teaching and learning. This corroborates Acholonu's explanation of the function of Oral literature (folktale); 'It was a realistic demonstration of accepted morals, ethical and cultural values.... Meant to be inculcated in the young ones with the purpose of integrating them functionally into the society'. Thus Raji (2009:302) in Ojo (2018:139) asserts: "'it preaches morals and emphasizes communal values, thereby helping to integrate groups and give them a sense of belonging'.

Integration is not a one man or one group (ethic group) exercise. In the instance of Nigeria, it required the collaborative effort of all Nigerians irrespective of group. Since it requires the common understanding of all, corpora of folktales from Igbo will be used for this study. The speculation is that similar folktales in all the groups especially the major groups: Hausa, Igbo and Yoruba express the same lessons. The only point of divergent is on the symbols used in the demonstration of a particular attribute or behavior, depending on the cultural perception of the object.

\section{EXAMPLES OF IGBO FOLKTALES}

In this section, samples of Igbo folktales would be narrated with the integration lessons discussed.

\section{> STORY 1: EKE MBE AGANA ESU}

Once upon a time there was famine in a given community, no rain, no water and the whole community converged, both animal and human being, to plan on how to dig a well. They all agreed to contribute and whosoever among them that does not contribute should not be allowed to fetch water from the well. All animals contributed only tortoise refused. They therefor put a night guard at the well side in order to prevent those that did not contribute for fetching water from the well. The tortoise designed a means to fetch from the well. He decorated himself with many objects in order to scare people he met on his way to the well. Anytime he goes to fetch water he would sing a song with the shaking of all the objects attached to his body. The song goes thus:

\section{Mbe- Eke mbe agana esu-(eke name of market day is about to start) \\ Chorus- Uyom uyo mbeneke Uyom \\ Mbe- Eke mbe agana esu- \\ Chorus- Uyom uyo mbeneke Uyom \\ Mbe - O chufuru nwaanyi, O chufuru nwoke (that \\ which scares woman, that which scares man) \\ Chorus- Uyom uyo mbeneke Uyom}

This song scared the security man the first time he heard it, because he could not assume how big or strong the person that was coming might be. A person who could not dared elephant or buffalo as big as they were, how much less of the ordinary night guard. So, he (the security man) ran away, while the tortoise fetched water to his satisfaction. When the whole communities came the following day to fetch water, they discovered someone had come to fetch the water. They therefore asked the security man of what went wrong and the security man explained to them that some spirit had been coming to fetch water in the mid night and all his efforts to catch him had been fruitless. He then promised that he would do all he could to make sure that the so called spirit was caught and apprehended to the whole community. The following day, the tortoise came again with his song together with all the noisy objects he attached to his body and leg that made it look like spirit.

Again, the security man could not stand. The communities therefore held another meeting. This time, they molded a small idol in the form of a small child with magnetic gum all over the body and mounted it at a conspicuous corner of the well. The tortoise came again singing the song, this time though the security known to him was absent. What he taught was small child boy(idol) stood there looking at him not moved or terrified. Then tortoise decided to beat the guard. He used the two handswhich glued to the idol, then the head until the whole body got glued to the idol. He could not move. The community and the guard came and met him.

\section{$>$ STORY 2. THE STORY OF OMALINZE}

This story tells us of a king who married many wives. He loved three but hated one (disintegration). None of the wives gave birth to a male issue who would be his successor as a result of atrocities committed by his father (the kings father) against many poor people. In the event of finding solution to the problem, he was advised to return to the poor all that his father wickedly collected from them. After the restitution, he was told by a native doctor (dibia) consulted to give each of the wives a specie of palm fruit called "akwu Ojukwu mmuo" which they were to use for cooking. He did so with the exclusion of the wife that he hated. As fate would have it, a lizard carried on of the nuts presumes to be rotten by one of the wives to the wife that was hated. She took it, used it to cook and there after became pregnant along with the other wives. As her source of pregnancy was a surprise so also her delivery of a male child among all the wives. Consequent upon her status, the maid who took charge of the delivery was afraid to narrate the incidence of her delivering a male child thereby threw the only baby boy and his mother inside a river. However, they were rescued by an old woman, who took care of them. The boy was left in the custody of the old woman. On the day of his delivery, the palace dog was a witness. So every day the dog would go visiting and kiss the feet of the boy. Meanwhile, the bot has heard that he was the son of the king. Each time the dog visited, the boy would sing:

\footnotetext{
Nkita Eze sa a o o

Nkita eze sa a o o

Nna $m$ eze nyere iwu

O muru nwoke kpolata

O muru nwaanyi tufuo

Odibo eze onye iwe

E wee muta $m$ tufuo

Odibe eze onye iwe
}

Nnyaa, Nnyaako
"
"
"
"
" 
On one occasion, there was a palm wine tapper who saw the boy and the king's dog and heard the song. He reported to the king who confirmed the report as true. The confusion then was, "who the mother was"; as all the wives laid claim in him. The conflict was resolved by the guidance of the trumpeter who directed him to the despised wife (his mother). This despised wife(disintegration) was restored (integrated) to royalty.

\section{STORY 3: NWA MMUO NU HURU NWA EGU M}

There was scarcity of firewood that demanded the attention of the members of the family. All the children with the consent of their parents went in search of firewood. After gathering of firewood, there was urged to search for any gem available in the bush, the last among them got a special gem-insect (egu) but forgot in the bush as they were going home. This demanded his going back to the bush which harbors evil spirits late in the evenings. In search of it, the boy was ill tempered likewise his other brothers. When he went in search of his gem (egu) he met evil spirits whom he did not regard, instead inquired of his gem rudely. The spirit cast a spell on him and he died. This happened to all the siblings who went one after the other in search of him. Meanwhile, there was a male servant despised by the parents of the children who volunteered to go in search of the children of his boss. Though he was refuted but he placed his life on the line in order to serve his boss and save their children. He was well behaved. When he was going, he saw an old woman who was despised by the earlier victims. He rendered help to her which made her to give him a charm which was an antidote to the spell of the evil spirit in the forest. He applied the charms as he was instructed by the old woman. This led to nullification of the spell of the evil spirit on the children and their subsequent restoration to their parents and the integration of the despised male servant into the full life of the family of his boss.

\section{IGBO FOLKTALES AND LESSONS FOR NATIONAL INTEGRATION}

A lot of integration lessons are deducible from these stories. The communities (likened to Nigeria) in these stories, comprises of human and animals with their diverse attributes (as Nigeria is blessed with many ethnic groups). As it is a common feature of folktales, animals can interact with human beings, spirits can interact with both human and animals. In the stories, there were problems which affected members of the community. In story 1 , there was the problem which affected all (animals and human) was the scarcity of water. In story 2 , it was the absence of a male successor to a king which turns round to be the problem of the entire community, while in story 3 it was the scarcity of firewood in the family which affected every member of the household which by extension suffixes for a community. In story 1, an assumed leader issued a command to all (both animals and humans) which they responded to. In story 2, the leader was the native doctor while in story 3 , the leaders were the parents. The introduction of the idol in story 1 , the dog in story
2 , and the spirits in story 3 represent the spirit world. The idol in story 1 was positioned to act as a mysterious guard, the dog in story 2 -a guide and the spirits in story 3 as both guard and guide. In the act of constructing the well in story 1, all of them (animal and human) participated according to respective expertise except the detractor -the tortoise. In the search for a male successor in story 2, all the women participated including the despised woman while in story 3 , all the children including the sidetracked slave participated.

Lesson: the young ones learn that in a chaotic situation any one can rise up to organize forces for a solution. Also, everyone's effort is necessary for the solution. Since the problem affects all there should not be a bench warmer, an observer or relegated but cooperating spirit (a gbakoo aka nyụo mmamiri o gboo ụfụfu). This is an act Saadu (2018:260) likened to the building of democracy' '...one will realize that in the course of building a viable democracy, there is need for people of like minds to come together...'

$>$ In the event of solving the problem, all of them put in their best. All were interested in finding solution to the problem. There were no marginalization, neither the human being, the animals nor the spirits claimed superiority over the other. They appreciated that each of them was uniquely endowed with potential.

Lesson: The young ones learn the spirit of understanding and appreciation of the uniqueness in other people.

Furthermore, all members of the communities (animals and humans) saw the problems from the same perspective. This made them to be sincerely committed to the solution.

Lesson: The young ones learn the attitude of being responsive to need of their community. Here no one was either forced out or pleaded with to be part of the solution. The spirit of commitment to the welfare of the community/society will be learnt. Because they all saw the problematic situation from the same angle, dissenting opinions were reduced to the barest minimum hence, distraction and discouragements which lead to disruption and destruction of purpose were sidelined.

In the stories, they were not acclaimed leaders that sent the call, yet everyone in the community responded. The call was for a genuine purpose.

Lesson: The youths learn that it is not only the instruction from the influential leaders that must be harkened to so long as it is for a reasonable purpose. Therefore, once there is a demand in the community /society, they as members are expected to make themselves available. 
The Igbo culture values consensus opinion hence 'a gbakoo aka nyuo mmamiri, o gboo ufufu When people urinate congregariously, it foams. In story 1 , this is demonstrated in their decision on what to do to Saboteur - he was not allowed to fetch water from the well. In story 2 , the king in obedience to consensus made the despised wife the palace wife against his will.

\section{Lesson: the youth learns to keep to agreed decision}

More still, the act of employing a guard at the well in story (1), the king's dog that monitored the male child in the strange land in story 2 , the slave boy in story 3 reveal the culture of adequate care and attention given to communal properties and ventures hence the Igbo belief that 'E jighi akpata atufuo aba ogaranya', you can not to get rich by wasting what is already acquired. Though the well belongs to the entire community, the succession of the throne -the kings problem it was not left as free for all.

Lesson: The youth learns the attitude of care for public property as well as his/her own belongings.

Still the same, when the culprit could not be apprehended by the guard, the entire community decided to introduce spirit disguised in the idol as a device to either scare or apprehend the rebel.

Lesson: This act develops in the youth the spirit of ingenuity especially when situations become cloudy; looking for solution beyond the immediate environment. This is a proof of all-round training in the traditional education that goes beyond the physical growth of the subject.

Furthermore, when the rebel (tortoise) was found glued to the idol (the guard), there was a unanimous decision on the punishment meted out on it. It (tortoise) was not an enemy to all members of the community yet when it was caught there was no counter opinion on how it should be treated. In this way, it was rid of and sanity was maintained.

Lesson: the youth learns societal values of not covering evil such as theft, cheating, sabotage e.t.c as well as respect for consensus decisions as a good member of the society.

All these lessons are very germane to the fostering of national integration. A process of creating a sense of national consciousness, uniqueness of identity and loyalty among people with different socio-cultural identity Endosa (2014:3) is what national integration stands for.

For there to be national integration, the citizens starting from the youth need to respond positively to proposals that are of benefits to the nation (the masses) irrespective of where the call is from (in this democratic dispensation, not minding the political party). People are so much to the ideologies of their political parties to the negligence of the wellbeing of the generality. This takes us back to what Adu-peters (2011:23) says.... The early elites who carelessly neglected the agitation for economic and socio independence for political independence of "now" ushered the entire polity into and incompatible dispensation of socio-political and economic entanglements.

Thee above deductions from the selected folktales which are generalizable to many folktales from other ethnic groups are corpora of what traditional education couched on the culture of the people aims to achieve. Flowing from changes in the educational policy from 1912 to 1977 ... the Nigerian child (Igbo child in particular) has been exposed to education that alienates him/her from his/her cultural expectation, which are intended to produce citizens exhibiting the above values, it becomes highly difficult for such individual or group to see and pursue (concern of the community) based on the common interest of the community. Emphasizing on the current secondary school curriculum, language study especially the native languages are optional.

The implication of this is that an Igbo child may go through primary, secondary and university education without having contact with his/her language either as a language of instruction or a language of study. Meanwhile, at home, in order to justify that their child is in the best of school, parents indulge in communicating with their children in English language. In those old days of 1970s and 80 s, in the school curriculum especially at the primary level, there was always a period for folktale under one of the trees in the in the school compound, we as children yearned for such periods. At the end of the narration, we were asked to present our lessons from the tale. Tales were not only narrated by the teacher, the pupils equally took part in the narration. This exercise was of great value in inculcating in us the morals the dos and don'ts, and the norms of the society. More so, it was a refreshing period that brings all children together according to their age range. We learned together, and made efforts at practicing the lessons learnt. We always reminded ourselves of the lessons should any of us deviate, hence there was integration starting at that level. All these are farce today because the avenues for such experience are no longer available both at home and at school.

\section{CONSEQUENCES}

Folktales narrated at home by parents to their children or communally during the moon light or taught in schools go long way in the teaching and learning of the language in which it is narrated. Language is the carrier of the society's culture as well as the means through which the culture is taught. Where it is neglected, the real essence of the society is in jeopardy if the definition of culture as "the way of life of the people" holds. The natural way of life of an Igbo man is centered on communal affection which are real life experience deposits in the folktales. Affirming to this, Das (g) explained that 'without oral tradition (preserved in the folktales sic) it will be difficult to get children themselves inculcated in the ethnic values of honesty and being each 
other's brothers' keeper. These values were imbibed in the type of stories we were told'. This is not the situation today.

The neglect of this veritable source of natural societal wisdom has played out in the level of crimes perpetuated by the youth toady. The three folktales in this study revealed the community values: protection and preservation of life, property and ascendency. The efforts of every member of the community were guided towards the same goal. No one considered individual benefits unlike what avails these days. The value for money at the expense of human life is at a high increase hence, the escalated level of kidnapping (either for ransom for or money ritual). The Boko Harams are on the other hand killing without reservation, threatening people into relocating from where their contributions made positive developmental impart to where their existence is dependent on charity. Worse still are the herdsmen. By these acts, people are not free to move about as they ought to. They are equally skeptical of making cogent contributions to issues of the nation because the suspicion is that the hoodlums have the support of some powers in the leadership of the country. With this, national integration remains a mirage.

Furthermore, the absence of the value for honesty and protection of communal interest is manifested in the activities of the yahoo boys/ girls and the yahoo plus. This is an act that is self-centered and against the communal interest which folktale preaches. It is practiced among the youth between ages 17-35, the age that should be at center of the labour force of the nation. By this dubious behavior, they pose themselves as threat to communal life and development. This is a great minus to national integration. The three folktales demonstrated the selflessness of all in protecting what was to be lost. On the contrary, these yahoo syndicates are selfish and steal what should be saved.

The great English Poet, T.S Eliot in Luke (2011) summarizes this thus: "the culture of the individual depends on the culture of the group" the child as a product of the community learns from the culture presented to him starting from the family down to the society. It knowledge that a child is given in the society forms him. This is because "Every action is made possible and constrained by culture (Eliot, ibid). When the child is not nurtured on the culture of the society/ group he becomes a deviant and a society that has lost the cultural values in the education of her youth will find it difficult to integrate her members. Bearing in mind that the societal culture transcends over the individual's, such children (consider the age of the youth perpetuating these scandalous acts) become out cast. By the increase of such individual in the society, the culture is threatened to extinction.

\section{THE FATE OF FOLKTAES IN NIGERIA: THE IGBO FOLKTALE EXAMPLE}

Integration thrives on unsuspicious acceptance of one by another. The ability to do this depends on the individuals who are moral, ethical, people who are inducted with shared value of society, has commitment to societal goals. These are the cultural values that folktales are intended to achieve. Therefore, the ability of the Igbo child to learn and live out the Igbo culture as emphasized in the folktale illustrated above, likewise the Yoruba and Hausa Child, will usher in national integrated. The reason is that ... 'the individuals as the units of integration and members of a nation are integrated as they share a common identity. Thus, the term national integration is not applicable to a single nation, but involves two or more nations'. Therefore, for there to be national integration, the Languages of the different nations (Hausa, Igbo, Yoruba, Ibibio, Efik etc) in Nigeria must be taught to their children starting from the primary through the secondary via the available avenues such as the folktales. It is a disheartening situation to note that this is not the case in Igbo society and generalizable to other societies. As Akubuilo (2018) puts it '...the problem we have today is the present generation of fathers and mothers: do they know any folktale to tell their children? Even if they know, when do they have the time to seat with their children?

The saddening situation is that the avenues for the sharing and imparting of these natural wisdoms for harmonious co-existence are no longer available. Modernity withal its presentations has deprived man of the avenues such as the moon light gathering where folktales narrations are at the space. The squares where the gatherings hold are no longer available. Community/individual building projects are erected in such places as against the communal purpose of leisure.

The installation of electric power supply has rendered the much valued, cherished and expected monthly appearance of the moon which is the bases for society gathering at the squares irrelevant. In the time past, the moon light was the cultural instance for folktales. It brought together men/women, old/young. These days, in its place, television, video, home videos (Nollywood), Instagram, Watsap, facebook and the like are preferred.

More so, the financial demands on parents have made it incumbent on both the parents and the youths to abandon the village for cities where such opportunities for folktale narration are not available. Much time is expended at that they only manage to come home to sleep. Worst still are parents who prevent their children from speaking their mother tongue. Akubuilo (2018) explained 'it is alarming that today's parents don't even allow their children to speak their native tongues... And when parents don't allow their children to speak their languages, what tales are they going to tell them? 
Furthermore, the sporadic establishment of private schools ( primary, secondary and university) where indigenous languages (NILS) are neither taught, learnt or spoken has gross affected the status of folktales. When Nigeria Education Policy has played down the status of indigenous languages in the government schools' curriculum is it the Private investor that will champion it? In this way, the average Nigerian child passes through the four walls of education without any contact with his/her language to talk of the folktale. With these therefore, the inculcation of societal morals, communal values which are essential ingredients for integration will be missing in the unit (the child who carries and replicate these lives). We just have to do everything possible to restore the lost values back to our national life. Our youths must not be allowed to imbibe wrong sentiments because it is what occupies their minds that determine the character. So, if want integration, the place of indigenous folktales as part of native language teaching must be revisited in the education policy of the nation.

\section{CONCLUSION}

In this study, it has been expatiated that folktales carry in them the societal values of co-operation, solidarity, honesty, harmony, obedience, and appreciation of one another's difference, ingenuity and care for one another. These are vital ingredients for national integration. As valuable as these elements are in the life of the nation, the channels through which they should be imparted in the youth on whom the united future of the nation rest, are not interested in its existence. The consequence of this, is a long profile of criminals arraigned by police on television daily, majority of whom are uninformed and uncultured youths. These are the ones who are susceptible to political manipulations, propagandas, rhetoric, cajoles and religious bigotry that pushes them to kill, maim, terrorize, and bomb innocent people. This paper calls for a re-think and re-plan on the indigenous languages status in the educational policy and curriculum of our schools for progress and development to be achieved through the process of national integration.

\section{RECOMMENDATIONS}

Nigerians should value their indigenous languages.

Values should be placed on indigenous cultures.

$>$ Folktale should be reintroduced in the schools' curriculum as part of Nigeria language learning, especially at the basic education level to impart rich traditional norms and values that are capable of producing responsible citizens.

$>$ The status of indigenous languages as languages for instruction in line with the provision of the National Policy on Education (NPE) should be revisited.

$>$ Parents should make their indigenous languages the medium of communication at home.

$>$ Parents should as well encourage their children to study Nigeria Indigenous Languages (NILS) and culture and sit for them in examinations starting from the JSSUniversity level.
Parents should create opportunities for the narration of folktale to their children. In this way the lesson inherent in them will be inculcated in the youth (the children).

$>$ No nation grows outside her culture, therefore, Government should encourage the study of NILS and culture by offering employment to graduates and scholarship opportunities.

\section{REFERENCES}

[1]. Adu-Peters, R. Olusola (2012). Nation Building and Quest for National Integration in Nigeria in Journal of Research in Education Science, Technology and Humanities (JORESTH) Vol.(1) -https://www. ( eaglesislandtech.blogspot.com 2012).

[2]. Https://www.quora.com what is the relationship and between language and culture,Darionne Garner(2016).

[3]. Ojo I.. F. and Fasehun Mercy Ayo (2018): Yoruba Oral Literature as A Panacea for Fostering Sustainable Socio-Geo Change in Nigeria. In S.A Akintunde, Bola Akinola, Olaniyan, R.F(eds). Lagos. Brown and Gold Prints Globalization of Perspectives in Nigerian Languages, Culture, Science and Technology. Pp. 139

[4]. Faturoti Olusegun Rotimi. 'An Insight Into Ethical and Behaviourial Patterns In Yoruba Proverbs"' in Kammelu N. C, Akinola, Onuegbu M. C. eds: Forms and Functions of Proverbs in Nigerian Languages. Ibadan: Alafas Nigeria Company. (2016) p. 348.

[5]. Ikeokwu, Ejike Sam. "Functionalism and the Pedagogy of Igbo Folktales"' in Journal of Igbo Studies In Journal of Igbo Studies. Vol. 2. Enugu: Igbo Studies Association, (2007). 22-25.

[6]. Aarons world of stories- folktale www.aaronshop.com>stories $>$ folk

[7]. Arohunmolese(2000:359). As oral tradition, it is passed orally from generation to generation.

[8]. Ibeh (2016). Folktale as Antistic Representation of History: A Study of Selected Igbo Folkales in Jounal of Arts and Design Studies. 